\title{
New data on the Afrotropical Xantholinini. 3. New species from Ethiopia of the Naturkundemuseum, Erfurt (Coleoptera, Staphylinidae) ${ }^{1}$
}

With 23 figures

ARnaldo Bordon ${ }^{2}$

${ }^{2}$ Museo di Storia Naturale dell’Università, di Firenze, sezione di Zoologia “La Specola”, via Romana 17, I-50125 Firenze, Italy. - arnaldo.bordoni@fastwebnet.it

Published on 2019-06-24

DOI: 10.21248/contrib.entomol.69.1.079-085

\section{Abstract}

Xantholinini of Ethiopia preserved in the Erfurt Naturkundemuseum were studied. The following new species are described and illustrated: Leptacinus riza spec. nov., Gyrohypnus aethiopicus spec. nov., G. oromianus spec. nov., Notolinopsis aethiopicus spec. nov., N. dodolanus spec. nov., Balchis oromiana spec. nov. and B. hartmanni spec. nov.

\section{Nomenclatur acts}

Leptacinus riza spec. nov. - urn:lsid:zoobank.org:act:CAEFF2A7-4E7E-435E-A27B-6A1B7DECB5C7 Gyrohypnus aethiopicus spec. nov. - urn:lsid:zoobank.org:act:B522E05B-83CE-40ED-9BB2-6B8889346129 Gyrohypnus oromianus spec. nov. - urn:lsid:zoobank.org:act:BB7E6499-4CFF-4284-AE1A-D93B06FA703F Notolinopsis aethiopicus spec. nov. - urn:lsid:zoobank.org:act:8023CD1F-4527-4606-93CF-95B0DCFEE682 Notolinopsis dodolanus spec. nov. - urn:Isid:zoobank.org:act:963F9C5A-8967-4309-9DAA-1BB3D34766D6 Balchis oromiana spec. nov. - urn:lsid:zoobank.org:act:504C405E-7F96-477E-96EC-334336EBFC05

Balchis hartmanni spec. nov. - urn:lsid:zoobank.org:act:13B9745D-404D-4037-BC3A-642C3BDB5D60

\section{Key words}

Coleoptera, Staphylinidae, Xantholinini, new species, Leptacinus, Gyrohypnus, Notolinopsis, Balchis, Ethiopia

\section{Zusammenfassung}

Im Naturkundemuseum Erfurt aufbewarte Xantholinini aus Äthiopien wurden untersucht. Die folgenden neuen Arten werden beschrieben und sind hier dargestellt: Leptacinus riza spec. nov., Gyrohypnus aethiopicus spec. nov., G. oromianus spec. nov., Notolinopsis aethiopicus spec. nov., N. dodolanus spec. nov., Balchis oromiana spec. nov. und B. hartmanni spec. nov.

\footnotetext{
${ }^{1} 291^{\circ}$ contribution to the knowledge of the Staphylinidae
} 


\section{Schlüsselwörter}

Coleoptera, Staphylinidae, Xantholinini, neue Arten, Leptacinus, Gyrohypnus, Notolinopsis, Balchis, Äthiopien

\section{Introduction}

Few specimens of Xantholinini from Ethiopia were listed in the revision of the Afrotropical species (BORDONI, 2016). Fruitful and interesting was the collection of specimens on the Bale, Enkuolo and Chillalo mountains in the province of Oromia, at high altitude. The results of the study of these specimens, preserved in the Erfurt Naturkundemuseum (NME) and in my private collection $(\mathrm{cB})$, are presented in this contribution.

Until now, the following Xantholinini were known from Ethiopia: Amharina trapeziceps (ScHeErpeltz, 1974), Homorocerus rufipennis BoHEMAN, 1848, Nudobius abessinus Bernhauer, 1915, N. proximus BernhaUer, 1915, N. coloriventris BernhaUer, 1915, Gauropterus abessinus Bordoni, 2016, Thyreocephalus alluaudi (FAuvel, 1907), T. ater (LAporte, 1835), T. pilosus (Roth, 1851), T. semipiceus Bernhauer, 1937, Gyrohypnus rougemonti BoRdoni, 2016, G. remotus (EPPELSHEIM, 1895), Endymathis aethiopica Bordoni, 2016, Achmonia congoensis (BERnHAuer, 1932), Phacophallus sahariensis Coiffait, 1968, Balchis abessina (Bernhauer, 1931), B. balensis BordonI, 2016, B. microptera (BERNHAUER, 1931), B. alpica Bordoni, 2016, Agaporina cooperi (Bernhauer, 1931), Elapheia aethiopica Bordoni, 2016, Byziniella africana (BERNHAUER, 1929), Chaetocinus aethiopicus BORDONI, 2016.

Only the genus Balchis seems to be endemic to Ethiopia. Other taxa are probably endemic of this region: Amharina trapeziceps, Nudobius proximus and N.coloriventris, Gyrohypnus rougemonti, Endymathis aethiopica, Agaporina cooperi, Elapheia aethiopica and Chaetocinus aethiopicus.

Therefore, with the new species described in these pages, the known Xantholinini of Ethiopia are thirty with one genus probably endemic.

\section{Descriptions of seven new species}

\section{Leptacinus riza spec. nov. \\ urn:Isid:zoobank.org:act:CAEFF2A7-4E7E-435E-A27B-6A1B7DECB5C7 (Figs 1-11)}

Examined material: Holotype $0^{-1}$ : Ethiopia, Oromia prov., S slope Bale Mts, below Riza, 2380 m, 08²3'17"N, $39^{\circ} 43^{\prime} 14$ "E, J. Schmidt 16.XII.2016 (NME); paratypes: same data, 1 ㅇ (NM), $1 \sigma^{\wedge}(\mathrm{cB})$.

Description: Length of body $5.2 \mathrm{~mm}$ from anterior margin of head to posterior margin of elytra: $2.9 \mathrm{~mm}$. Body (Fig. 1) narrow, charatcerized by dark color, fine and relatively dense punctation on pronotum, apart a medium stripe, and by long elytra. Body reddish brown very dark; antennae and legs brown. Head sub-rectangular, narrowed anteriad, with very moderately rounded sides and narrowly rounded posterior angles. Eyes small and flat. Surface of head shiny, with traces of transverse micro-striation and deep, moderately sparse punctation, apart a narrow median stripe. Pronotum sub-rectangular, a little dilated anteriad, longer and narrower than head, with oblique anterior margins, rounded anterior angles and scarcely sinuate sides. Surface shiny, without micro-sculpture, with dorsal series of 10-11 deep punctures and lateral series of 6-7 irregular punctures; other punctures between these series and near the anterior angles. Elytra large, dilated posteriad, longer and wider than pronotum, with sub-rectilinear sides and rounded humeral angles. Surface with deep, moderately dense punctation, arranged in numerous series. Abdomen with transverse micro-striation and fine punctation on the sides.

Tergite and sternite of the male genital segment as in Figs 9-10. Aedeagus (Fig. 2) $1 \mathrm{~mm}$ long, ovoid, with long median lobe; inner sac broad, covered with regular scales; parameres long and narrow.

Etymology: The specific epithet refers to the type locality, as a noun in apposition.

Distribution: The species is known only from the type locality.

Remarks: The genus Leptacinus ERICHSON, 1839 occurs in Europe but also in North Africa, Middle East, Turkey, Caucasus and to Yemen (Bordoni, 2010). The new species is attributed to this genus, but I think it is appropriate to underline some just divergent characters partially also highlighted in the proposed figures (Figs 1-11): in particular structure of mandible, maxillary and labial palpi, shape of mesosternum, male genitalia and female genital segment.

The genus Leptacinus is related to Balchis BordonI, 2016 from Ethiopia by the external characters but differs however by the following characters: different maxillary and labial palpi; $2^{\text {nd }}$ antennomere a little longer than 3 rd; ocular and frontal grooves present; different sternum; gular sutures not V-shaped and not separated for almost their entire length; different upper epipleural line; aedeagus.

This is the first Leptacinus known from Ethiopia. 
Gyrohypnus aethiopicus spec. nov. urn:Isid:zoobank.org:act:B522E05B-83CE-40ED-9BB2-6B8889346129 (Figs 12-14)

Examined material: Holotype $\sigma^{*}$ : Ethiopia, Oromia prov., SW slope Mt Chillalo, $2985 \mathrm{~m}, 07^{\circ} 33^{\prime} 31^{\prime \prime N}, 39^{\circ} 10^{\prime} 18^{\prime \prime} \mathrm{E}$, J. Schmidt 30.XI.2016 (NME).

Description: Length of body $11.5 \mathrm{~mm}$, from anterior margin of head to posterior margin of elytra: $6 \mathrm{~mm}$. Body black; antennae and legs brown. Head sub-rectangular, narrowed anteriad, with moderately rounded sides and narrowly rounded posterior angles. Eyes small and almost flat. Surface of head with deep, very dense punctation, apart a narrow median stripe. Some setiferous punctures near the eyes and the posterior angles. Pronotum dilated anteriad, as long as head, slightly narrower than it, with oblique anterior margins, rounded anterior angles and sinuate sides. Surface shiny, with dorsal series of 10-11 very irregular punctures and lateral, oblique series of 8-9 punctures; other punctures near the anterior angles. Elytra dilated posteriad, longer and wider than pronotum, with sub-rectilinear sides and rounded humeral angles. Surface with numerous, very fine, dense punctures, arranged in numerous series. Abdomen partially wrinkled, with evident punctation, arranged in numerous series on each segment.

Tergite and sternite of the male genital segment as in Figs 12-13. Aedeagus (Fig. 14) $2.6 \mathrm{~mm}$ long, large, subrectangular, with characteristic distal portion; parameres short, broad, provided with evident setae; inner sac tapelike, long and narrow, folded on itself one time, covered with very fine, longitudinal spinulae.

Etymology: The specific epithet refers to Ethiopia.

Distribution: The species is known only from the type locality.

Remarks: The genus Gyrohypnus LeACH, 1819 is represented in Africa south of Sahara by 8 species, especially in the central regions (Congo, Uganda, Kenya), apart from the aforementioned $G$. rougemonti, probably endemic to Ethiopia (BORDONI, 2016).

\section{Gyrohypnus oromianus spec. nov. urn:Isid:zoobank.org:act:BB7E6499-4CFF-4284-AE1A-D93B06FA703F}

Examined material: Holotype + Ethiopia, Oromia prov., Mt Enkuolo, NE slope, 3100-3200 m, 07²4'41"N, $39^{\circ} 22^{\prime} 26^{\prime \prime E}$ J. Schmidt 5-7.XII.2016 (NME).

Description: Length of body $10 \mathrm{~mm}$, from anterior margin of head to posterior margin of elytra: $5.4 \mathrm{~mm}$. Head and pronotum black, elytra black with more than back half red, abdomen reddish brown with reddish paratergites; antennae and legs brown black. Similar to
G. aethiopicus sp. n. but smaller, narrower, with different color; head very similar but with less dense punctation, absent on a median stripe and very superficial at the inner side of the eyes; lateral portion of head without punctation, shiny; eyes smaller; pronotum narrower, less dilated anteriad, with more rounded anterior angles and finer punctation; dorsal series of 3-4 anterior punctures and 5-6 posterior punctures; elytra shorter and narrower, less dilated posteriad, with more marked humeral angles; abdomen shiny.

Sixth visible abdominal tergite with a median, rectangular protrusion.

Male unknown.

Etymology: The specific epithet refers to Oromia province.

Distribution: The species is known only from the type locality.

Remarks: In Ethiopia occurs two species of this genus, G. remotus, also known from Kenya and Congo (Bordoni, 2016) and G. rougemonti, endemic taxon (Arussi prov.). To this last species G. oromianus spec. nov. differs by the following characters: longer and narrower body, different color; head anteriad more narrow, with sparser punctation; eyes smaller and in a more lateral position; more protruding epistoma; narrower pronotum, with different punctation; smaller elytra.

G. remotus is a very smaller species ( $7 \mathrm{~mm}$ long), brown black with reddish pronotum, visible abdominal segments $5^{\text {th }}$ and $6^{\text {th }}$ and genital segment; different punctation on pronotum and elytra. The new species in fact is immediately distinguished from congeners for coloring.

\section{Notolinopsis aethiopicus spec. nov. urn:Isid:zoobank.org:act:8023CD1F-4527-4606-93CF-95B0DCFEE682 (Figs 15-17)}

Examined material: Holotype $\sigma^{\star}$ : Ethiopia, Oromia prov., S slope Bale Mts, below Riza, $2380 \mathrm{~m}, 08^{\circ} 43^{\prime} 17^{\prime \prime} \mathrm{N}$, $39^{\circ} 43^{\prime} 14$ "E, J. Schmidt 16.XII.2016 (NME); paratypes: same data, $10^{x}, 4$ 우 (NME), $10^{x}, 1$ 우 (cB).

Description: Length of body $6.2 \mathrm{~mm}$, from anterior margin of head to posterior margin of elytra: $3 \mathrm{~mm}$. Apterous, reddish brown species. Head sub-rectangular, moderately narrow anteriad, with sub-rectilinear sides and narrowly rounded posterior angles. Eyes small and almost flat. Surface of head with fine, dense, transverse micro-striation and deep, very sparse punctation, apart a wide median stripe. Pronotum massive, of the same width anteriad and posteriad, longer and a little wider than head, with barely rounded sides, very oblique anterior margins continued laterally up to the mid of the pronotum, with almost obsolete anterior angles. Surface similar to that of head, with dorsal series of 6 
deep punctures and lateral series of 5-6 finer punctures. Elytra shorter and narrower than pronotum, with barely rounded sides and obsolete humeral angles. Surface with fine punctation, arranged in numerous series. Abdomen with fine, more or less transverse micro-striation and fine, dense punctation, arranged in numerous series on each segment.

Tergite and sternite of the male genital segment as in Figs 15-16. Aedeagus (Fig. 17) $1.4 \mathrm{~mm}$ long, ovoid, with long distal lobule and long, narrow, asymmetrical parameres; inner sac tape-like, long and narrow, folded on itself and covered with closed spines, finer in the proximal portion.

Etymology: The specific epithet refers to Ethiopia.

Distribution: The species is known only from the type locality.

Remarks: The genus Notolinopsis CASEY, 1906 (sensu Bordoni, 2016) is represented in Africa South of Sahara by two groups of species, one in South Africa, composed by winged species, with body more or less dark brown, evident eyes and normally shaped elytra (23 species), and one in Congo, Tanzania and Kenya, composed by apterous species, with body more or less yellowish brown, eyes small and flat and short elytra (13 species) (BordonI, 2016).

The collection of some specimens of Notolinopsis in Ethiopia is of important biogeographical interest as it considerably widens to the north the distribution area of the species of the second group mentioned above, especially since the known species occuring in the mountains of the Kivu region and on the Kilimajaro, Elgon and Kenia mountains, under stones but especially in humus of bamboo forests, very far to the Ethiopian borders.

\section{Notolinopsis dodolanus spec. nov.}

urn:Isid:zoobank.org:act:963F9C5A-8967-4309-9DAA-1BB3D34766D6

Examined material: Holotype + : Ethiopia, Oromia prov., Western Bale Mts, abov. Dodola, 2700-2850 m, $06^{\circ} 53^{\prime} 49^{\prime \prime N}$, 39¹1'32"E, J. Schmidt 10-11.XII.2016 (NME); paratype: 1 \% (cB).

Description: Length of body $8 \mathrm{~mm}$, from anterior margin of head to posterior margin of elytra: $4.8 \mathrm{~mm}$. Apterous, reddish brown with brown light antennae and legs. Head ovoid, moderately narrowed anteriad, with barely rounded sides and narrowly rounded posterior angles. Eyes small and flat. Surface of head with more or less transverse, fine and dense micro-striation and deep, sparse punctation, apart a median stripe. Pronotum massive, sub-parallel, longer and wider than head, with sub-rectilinear sides, and anterior margins widely rounded from the neck up to half the length of prono- tum. Surface similar to that of head, with dorsal series of 6-7 deep, very sparse punctures and lateral series of 4-5 punctures. Elytra short, sub-rectangular, shorter and narrower than pronotum, with sub-rectilinear sides and obsolete humeral angles. Surface wrinkled, with numerous series of deep, sparse punctures. Abdomen with more or less transverse, fine and dense micro-striation and fine but evident, dense punctures, arranged in numerous series on each segment.

Male unknown.

Etymology: The specific epithet refers to the type locality.

Distribution: The species is known only from the type locality.

Remarks: I describe this species, although it is a female, because, having studied the Afrotropical Xantholinini (Bordoni, 2016), I know for sure that no Notolinopsis of Ethiopia were known, since the genus occurs only in South Africa, Congo, Kenya and Tanzania, with different taxa. The two species here described are different between them for several exoskeletal characters. In particular Notolinopsis dodolanus spec. nov. differs from N. aethiopicus spec. nov. by very larger body, darker color, broader head and pronotum, deeper punctation on head, pronotum and elytra, longer and wider elytra, with denser punctation.

\section{Balchis microptera (BERNHAUER, 1931)}

Examined material: Ethiopia, Oromia prov., SW slope Mt Chillalo, $3000-3300 \mathrm{~m} \quad 07^{\circ} 54^{\prime} 01^{\prime \prime N}, \quad 39^{\circ} 11^{\prime} 26^{\prime \prime} \mathrm{E}$, J. Schmidt 2.XII.22016, 1 우 (NME).

Distribution: This taxon is known only for the holotype o of Mt Chillalo. First record since the description of the species.

Remarks: The male genital segment of Balchis BoRDONI, 2016 is peculiar; in fact the pleurae are visibly swollen and well separated by the tergite. This genus seems endemic to Ethiopia and was represented untill now by four species, as indicated in the introduction, from Djem Djem forest (or Djam) near Addis Abeba, Mt Chillalo and Mt Bale (Bordoni, 2016).

\section{Balchis oromiana spec. nov.}

\section{urn:Isid:zoobank.org:act:504C405E-7F96-477E-96EC-334336EBFC05}

(Figs 18-20)

Examined material: Holotype $\sigma^{*}$ : Ethiopia, Oromia prov., above Dodola, 3400-3700 m, 06.51N, 39.14E, J. Schmidt 12.XII.2016 (NME); paratypes: same data, 4 우 우 (NME), 1 o $^{\star}, 1$ 우 (cB). 
Description: Length of body $7,5 \mathrm{~mm}$, from anterior margin of head to posterior margin of elytra: $3.5 \mathrm{~mm}$. Brachypterous, reddish brown very dark with brown antennae and legs. Head ovoid elongate, barely narrow anteriad, with moderately rounded sides and narrowly rounded posterior angles. Eyes vey small and flat. Surface of head with very fine, dense, transverse microstriation and scattered, deep punctation, apart a wide median stripe. Pronotum massive, moderately dilated anteriad, longer than head, as wide as it, with very oblique anterior margins and widely rounded anterior angles. Surface similar to that of head, with dorsal series of 10-11 punctures and lateral series of 6-7 irregular punctures; other punctures near the anterior angles. Elytra short, moderately dilated posteriad, shorter and a little narrower than pronotum, with obsolete humeral angles. Surface wrinkled, with fine, sparse punctation, arranged in some series. Abdomen with transverse micro-striation and sparse punctation, arranged in some series on each segment.

Tergite and sternite of the male genital segment as in Figs 18-19. Aedeagus (Fig. 20) $0.7 \mathrm{~mm}$ long, subspherical, with asymmetric, long parameres, dilated in the proximal portion; distal lobule sub-rectangular; inner sac partially everted, indefinable, with some, very fine spinulae.

Etymology: The specific epithet refers to Oromia province.

Distribution: The species is known only from the type locality.

Remarks: This species differs from its congeners by larger size, darker color and genitalia.

\section{Balchis hartmanni spec. nov.}

urn:Isid:zoobank.org:act:13B9745D-404D-4037-BC3A-642C3BDB5D60

(Figs 21-23)

Examined material: Holotype $\sigma^{\star}$ : Ethiopia, Oromia prov., Mt Enkuolo, NE slope, $3200-3300 \mathrm{~m}, 07^{\circ} 23^{\prime} 45^{\prime \prime} \mathrm{N}$, $39^{\circ} 22^{\prime 2} 27^{\prime \prime E}$, J. Schmidt 8.XII.2016 (NME); paratypes:

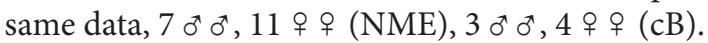

Description: Length of body $6.3 \mathrm{~mm}$, from anterior margin of head to posterior margin of elytra: $2.7 \mathrm{~mm}$. Brachypterous, reddish brown with lighter antennae and legs. Head ovoid with rounded sides and almost obsolete posterior angles. Eyes very small and flat. Similar to B. alpica BoRDONI, 2016 but body robustior and darker; head less dilated anteriad, laterally with deeper and denser punctation; pronotum not sub-rectangular, sub-ovoid, more dilated anteriad, with more oblique anterior margins and with deeper punctation.

Tergite and sternite of the male genital segment as in Figs 21-22. Aedeagus (Fig. 23) $0.55 \mathrm{~mm}$ long, sub- spherical, with asymmetric parameres, the right dilated in the proximal portion; distal lobule sub-rectangular with sub-acute apex; inner sac partially everted, indefinable, with some, very fine scales.

Etymology: Patronymic. Dedicated as a sign of esteem to the friend and colleague Dr. Matthias Hartmann, Director of the Naturkundemuseum of Erfurt.

Distribution: The species is known only from the type locality.

\section{Acknowledgements}

I wish to thank Dr. Matthias Hartmann, Director of the Naturkundemuseum of Erfurt, who sent me these interesting specimens to the studio, Prof. T. Schmitt (Director of the Senckenberg Deutsches Entomologisches Institut, Müncheberg) for the useful collaboration, and Silvio Cuoco (Livorno) for the nice photos.

\section{References}

Bernhauer, M. 1915: Zur Staphyliniden-fauna des tropischen Afrika. - Annales Musei Nationalis Hungarici 13: 95-189.

Bernhauer, M. 1929: Zur Staphylinidenfauna des belgischen Kongstaates. - Verhandlungen der k. k. zoologisch-botanischen Gesellschaft in Wien $\mathbf{7 8}$ (1928): 106-131.

Bernhauer, M. 1931: Part II. Systematic. pp. 565-605. - In: Bernhauer, M. \& Scott, H.: Entomological Expedition in Abyssinia, 1926-7: Coleoptera, Staphylinidae. - The Journal of the Linnean Society of London, Zoology 37: 559-605.

Bernhauer, M. 1932: Neue Kurzflügler aus dem belgischen Kongostaate. - Revue de Zoologie et de Botanique Africains 22: 140-174.

Bernhauer, M. 1937: Beitrag zur afrikanischen Staphylinidenfauna. - The Annals and Magazine of Natural History 10 (18): 321-336.

Boheman, C. H. 1848: Insecta Caffrariae annis 18381845 a J. A. Wahlberg collecta. 1 (1) Coleoptera (Carabici, Hydrocanthari, Gyrinii et Staphylinii). Holmiae: Norstedtiana, xiii +297 pp.

Bordoni, A. 2002: Xantholinini della Regione Orientale (Coleoptera: Staphylinidae). Classificazione, Filogenesi e Revisione Tassonomica. Volume 33: Monografie di Museo Regionale di Scienze Naturali - Museo Regionale di Scienze Naturali, Torino: 998 pp. - ISBN 8886041454 - http://www.nhbs.com/ xantholinini-della-regione-orientale-coleopterastaphylinidae-classificazione-filogenesi-e-revisionetassonomica-xantholinini-of-the-oriental-coleoptera-staphylinidae-classification-phylogeny-andtaxonomic-revision-book [accessed 2017/10/11]. 
Bordoni, A. 2010: Allolinus CoIffait, 1966 nuovo sinonimo di Leptacinus ErICHson, 1839 e descrizione di Leptacinus yemeniticus nov. spec. dello Yemen (Coleoptera, Staphylinidae). - Bollettino della Società entomologica italiana 142 (2): 77-79.

Bordoni, A. 2016: Revision of the Afrotropical Xantholinini (Coleoptera, Staphylinidae). Biodiversity Journal 7 (4): 389-894.

Bordoni, A. 2017: New data on the Afrotropical Xanholinini. 1. New species from South Africa in the Janak collection (Coleoptera, Staphilinidae). - Linzer biologische Beiträge 49 (2): 1233-1243.

Casey, T. L. 1906: Observations on the staphylinid groups Aleocharinae and Xanholinini chiefly of America. Transaction of the Academy of Sciences of St. Louis 16: $125-434$.

Coiffait, H. 1968: Coléoptères Staphylinides récoltés par J. Mateu dans l'Ennedi. - Bulletin de l'Institut Fondamental d'Afrique Noire (I.F.A.N.) Ser. A 30 (1): 135-150.

Eppelsheim, E. 1895: XII. Staphylinidae. - In: Esplorazione del Giuba e dei suoi affluenti compiuta dal Cap. V. Bottego durante gli anni 1892-93 sotto gli auspici della Società Geografica Italiana. Risultati Zoologici. - Annali del Museo Civico di Storia Naturale di Genova 15 (2): 195-213.

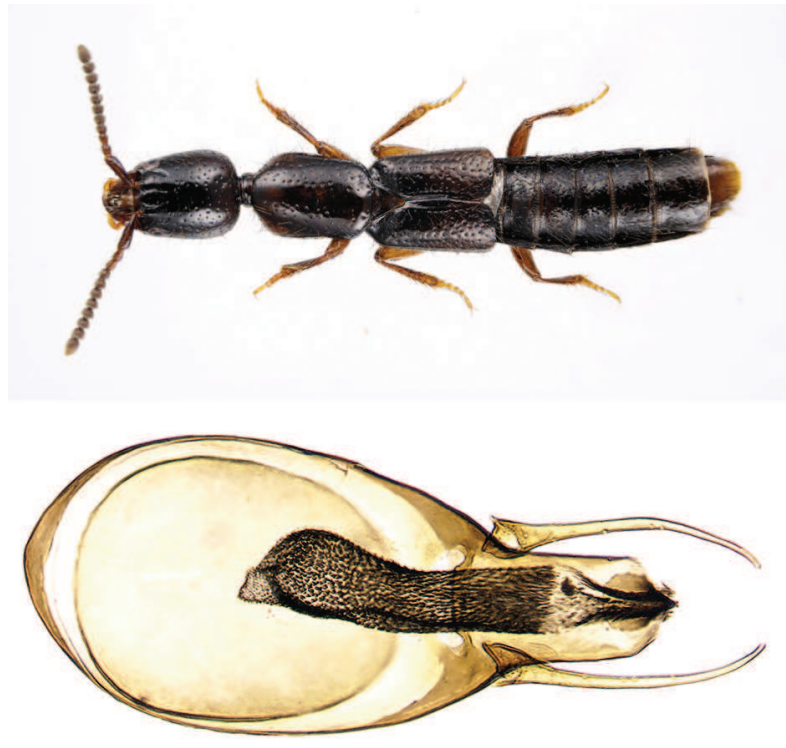

Figs 1-2: Leptacinus riza spec. nov.: habitus (1) (total length $5.2 \mathrm{~mm}$ ) and aedeagus (2) (total length $1 \mathrm{~mm}$ ) (photo S. Cuoco).
ErICHSON, W. F. 1839: Genera et species Staphylinorum insectorum coleopterorum familiae. - F. H. Morin, Berlin: $954 \mathrm{pp}$.

Fauvel, A. 1907: Voyage de M. Ch. Alluaud dans l'Afrique Orientale. Staphylinidae. - Revue d'Entomologie 26: 10-70.

LAPORTE, F. L. 1835: Études entomologiques, ou description d'insectes nouveax, et observations sur leur synonymie. - Méquignon-Marvis, Paris: 159 pp.

LeAch, W. E. 1819: Staphylinidae. - In: SAmouelle, G.: The Entomologists useful compendium or an introduction to the knowledge of British Insects, London: $496 \mathrm{pp}$.

Roth, J. R. 1851: Diagnosen neuer Coleoptera aus Abyssinien. - Arkiv für Naturgeschichte 17: $115-133$.

Scheerpeltz, O. 1974: Coleoptera aus Nordostafrika, Staphylinidae. - Acta Entomologica Fennica 31: 3-49.

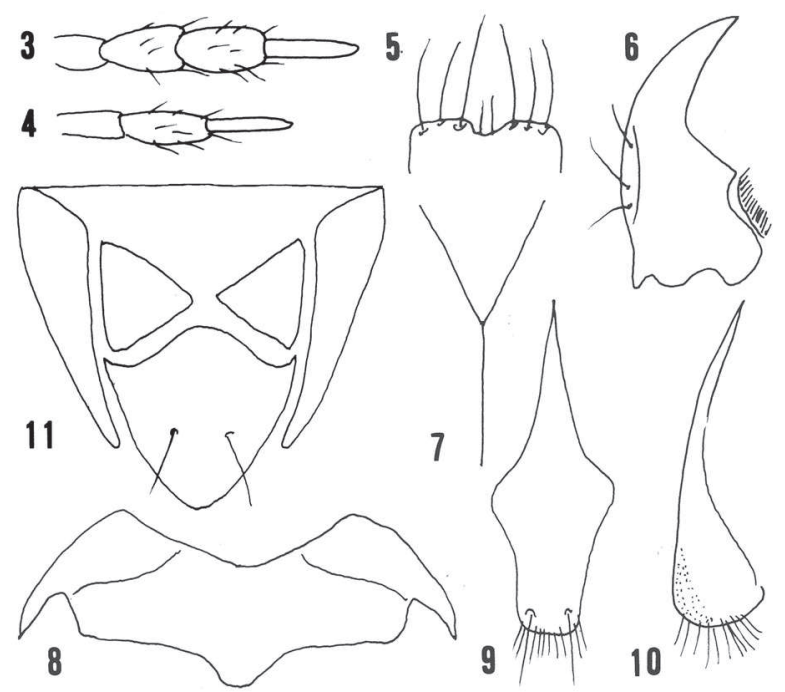

Figs 3-11: Leptacinus riza spec. nov.: maxillary palpi (3), labial palpi (4), labrum (5), mandible (6), gular sutures (7), mesosternum (8), tergite (9) and sternite (10) of the male genital segment, female genital segment (11). 

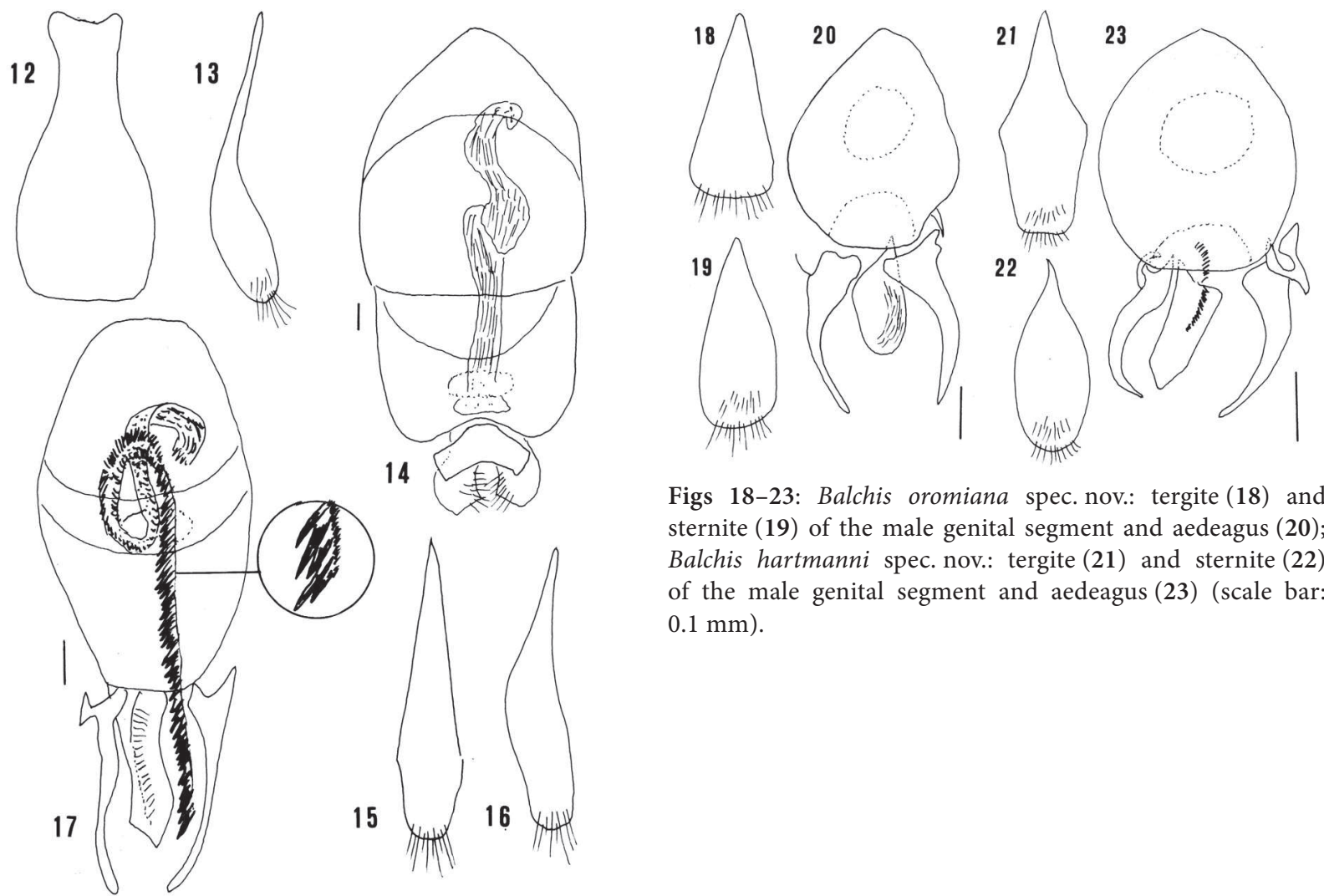

Figs 18-23: Balchis oromiana spec. nov.: tergite (18) and sternite (19) of the male genital segment and aedeagus (20); Balchis hartmanni spec. nov.: tergite (21) and sternite (22) of the male genital segment and aedeagus (23) (scale bar: $0.1 \mathrm{~mm})$.

Figs 12-17: Gyrohypnus aethiopicus spec. nov.: tergite (12) and sternite (13) of the male genital segment and aedeagus (14); Notolinopsis aethiopicus spec. nov.: tergite (15) and sternite (16) of the male genital segment and aedeagus (17) (scale bar: $0.1 \mathrm{~mm})$. 